\title{
Low energy availability and low body fat of female gymnasts before an international competition
}

\author{
M.-R. G. SILVA $^{1,2,3,4}$, T. PAIVA ${ }^{1,5}$ \\ ${ }^{1}$ Institute of Molecular Medicine, Medical Faculty of Lisbon, Lisbon, Portugal, ${ }^{2}$ Faculty of Health Sciences, University \\ Fernando Pessoa, Oporto, Portugal, ${ }^{3}$ Scientific Commission of the National School of Gymnastics, Gymnastics Federation of \\ Portugal, Lisbon, Portugal, ${ }^{4}$ Research Centre for Anthropology and Health, University of Coimbra, Coimbra, Portugal, \\ ${ }^{5}$ CENC, Sleep Medicine Center, Lisbon, Portugal
}

Corresponding author: M.-R. G. Silva, raquel@ufp.edu.pt

\begin{abstract}
The purpose of the present study was to evaluate dietary intake and body composition of elite rhythmic gymnastics (RG) athletes prior to a competition event. Sixty-seven rhythmic gymnasts $(18.7 \pm 2.9$ years old $)$ of high performance level, with $36.6 \pm 7.6 \mathrm{~h}$ of training/week were evaluated in order to collect training and competition data, medical and gynaecological history, detailed dietary intake and body composition before an international competition. The majority of the participants $(\mathrm{n}=40 ; 59.7 \%)$ had already menstruated, but age of menarche was delayed $(15.3 \pm 1.3$ years $)$ and all revealed menstrual irregularities. Gymnasts' body mass $\left(48.4 \pm 4.9 \mathrm{~kg}\right.$ ) and body mass index (BMI; $\left.17.4 \pm 1.1 \mathrm{~kg} / \mathrm{m}^{2}\right)$ were below the normal for age, and height $(1.66 \pm 0.05 \mathrm{~m})$ was normal or even slightly above normal for age. Body fat was $9.0 \pm 2.0 \%$ with no significant differences between age strata. Gymnasts exhibited low energy availability (EA; $31.5 \pm 11.9 \mathrm{kcal} / \mathrm{kg}$ fat-free mass (FFM)/day). The average carbohydrate and protein intakes were $5.1 \pm 2.3 \mathrm{~g} / \mathrm{kg} / \mathrm{day}$ and $1.6 \pm 04 \mathrm{~g} / \mathrm{kg} / \mathrm{day}$, which correspond to $51.4 \pm 7.2 \%$ and $16.9 \pm 3.4 \%$ of total energy intakes, respectively; average fat contribution was $33.0 \pm 5.3 \%$. Low intakes of pantothenic acid, folate and vitamins $\mathrm{D}, \mathrm{E}$ and $\mathrm{K}$ and of minerals, including calcium, iron and magnesium were reported. Intakes of thiamine, riboflavin, niacin, vitamins A, B-6, B-12, C and manganese and zinc were above-adequate $(\mathrm{P}<0.05)$. Low EA, low body fat and micronutrient deficiencies are common among RG.
\end{abstract}

Keywords: Energy availability, energy intake, macronutrients, micronutrients, body composition, female athletes

\section{Introduction}

Rhythmic gymnastics (RG) is an Olympic female sport, considered a highly specialised discipline involving the use of five hand apparatuses (rope, ball, hoop, clubs and ribbon). Competitive routines last between 60 and $90 \mathrm{~s}$ with each apparatus and result from the combination of several different body elements that require high-intensity effort with a unique dexterous manipulation of apparatus. Therefore, dynamic and static balance is necessary in balance positions, jumps and rotations; explosive strength is a determinant for dynamic elements with rotation and throw, jumps and pre-acrobatic movements; flexibility is dominant during all body elements and coordination is a determinant for dance steps combination with apparatus mastery (Calavalle et al., 2008). Adequate cardiovascular and musculoskeletal systems, regular endurance training to tolerate strenuous exercise (Douda, Toubekis, Avloniti, \& Tokmakidis, 2008) and aerobic and anaerobic metabolism (high-energy phosphate and glycolysis) seem to be determinant of high performance levels (Baldari \& Guidetti, 2001; Douda et al., 2008). In addition, leanness is also a valuable prerequisite for technical performance and is considered more aesthetically pleasing to judges and for selection at an elite level (D'Alessandro et al., 2007; Michopoulou et al., 2011). However, a reduced body mass (BM) often leads gymnasts to inadequate energy intake (EI) compromising adequate energy levels for gymnasts' growth, daily activities and athletic performance. Inadequate EI can also cause a decrease in the basal metabolic rate (BMR) and a relative increase in fat storage (Deutz, Bernardot, Martin, \& Cody, 2000), i.e., it functions in a way opposite to that 
required. Therefore, depending on the intensity, type and duration of physical exercise (Jeukendrup \& Cronin, 2011), carbohydrates are the recommended main energy source (Rodriguez et al., 2009), ensuring in that way adequate levels of blood glucose and of muscle and hepatic glycogen.

Gymnasts train intensively from very young ages and maintain that training regime during adolescence and early adulthood. During this time, significant changes in body size occur, influencing physiological and physical performance. Thus, in the short term, energy availability (EA) is required to improve gymnasts' health, to prevent injury and, in the long term, sustained low EA (LEA) may predispose the female athletes to various health hazards such as irregular menstruation, infertility and osteoporosis (Loucks, Kiens, \& Wright, 2011). For this reason, the main purpose of this study was to evaluate energy and nutrients intake and body composition, in high performance gymnasts before an international competition.

\section{Methods}

\subsection{Participants}

Sixty-seven rhythmic gymnasts $(\mathrm{RG})(18.7 \pm 2.9$ years old) of high performance level $(36.6 \pm 7.6 \mathrm{~h}$ of training/week) with $11.5 \pm 3.2$ years of practice of RG were evaluated between 1 and 4 days before an international competition, the FIG World Cup 2011 and the RG International Tournament, which took place in Portimão, Portugal. The gymnasts were asked to complete a questionnaire of training routines, medical and gynaecological history, typical dietary intake and body composition. In accordance with delegations' arrival, athletes were recruited through personal contacts or through their coaches and volunteered to participate. Study design was approved by the Ethical Committee of the Medical Faculty of Lisbon and written informed consent was obtained from participants. From the 115 gymnasts in competition, the response rate was $58.2 \%(n=67)$. Due to growth and dietary issues athletes were subdivided in two subgroups: from 16-18 years to 19-26 years.

\subsection{Training and competition data}

Training volume was defined as hours per week and competition data was obtained from the published final list of general competition results.

\subsection{Medical and gynaecological history}

Age at menarche, changes in menstrual cycle, oral contraceptive use and any kind of medication, vitamin or mineral supplement or any other type of supplement were collected. Regular menstrual cycles were defined as menses occurring every 28-30 days. The presence of primary amenorrhea, secondary amenorrhea and oligomenorrhea as defined by the American Society for Reproductive Medicine (ASRM, 2008) were considered as menstrual irregularities.

\subsection{Body composition}

BM was measured by a digital scale (SECA-872, Hamburg, Germany) to the nearest $0.01 \mathrm{~kg}$ wearing T-shirt and gym shorts before training. Height was determined with a portable stadiometer (SECA-213, Hamburg, Germany) to the nearest $0.1 \mathrm{~cm}$. Procedures were conducted as recommended by the International Society for the Advancement of Kinanthropometry (Marfell-Jones, 2006). BM index (BMI) was calculated as a ratio of weight to the squared height $\left(\mathrm{kg} / \mathrm{m}^{2}\right)$. Anthropometric standards from Frisancho (2008) were used for BM, height and BMI. The waist circumference (WC) was measured with a flexible tape at the end of a normal expiration at the smallest circumference between the thorax and the hips. The hip circumference (HC) was measured with a flexible tape at the largest circumference on trochanters and Waist/Hip Ratio (WHR) was calculated. Body fat (BF), total body water (TBW) and fat-free mass (FFM) were assessed by bio-impedance analysis (TANITABC-545, UK).

\subsection{Dietary assessment}

Energy and nutrient intake was assessed from the previous $24 \mathrm{~h}$ record. Gymnasts were very time limited between and within training sessions and preparing to compete, therefore, applying for more than one day for dietary intakes was difficult and food consumption accurately reflected the period of interest (Magkos \& Yannakoulia, 2003). Participants were asked to record all foods and beverages typically consumed for the $24 \mathrm{~h}$ before the interview, including time of day and meal type (e.g. breakfast). Foods were expressed in household measurements. The household measurements were converted to grams and millilitres for a quantitative analysis. Nutrient data were coded and analysed with Food Processor SQL. Foods and preparations not included in the database provided by the programme were included by a complementary nutritional information table or based on information contained on the labels of the industrialised products. The daily dietary analyses included energy, carbohydrates and proteins based on body size, percentage of fat, thiamine, riboflavin, niacin, pantothenic acid, vitamin B-6, folate, vitamin B-12, vitamin A, vitamin $\mathrm{C}$, vitamin $\mathrm{D}$, vitamin $\mathrm{E}$, vitamin $\mathrm{K}$, calcium, iron, boron, magnesium, manganese, phosphorus, zinc, fibre and water. The recommended level of protein 
intake by the American College of Sports Medicine (ACSM) (Nattiv et al., 2007) was 1.2-1.6 g/ $/ \mathrm{kg} / \mathrm{day}$. Using the recommendations of the American Dietetic Association, (ADA) the Dieticians of Canada and the ACSM (Rodriguez et al., 2009) and Manore, Kam, Loucks, and International Association of Athletics Federations (2007), the recommended levels of carbohydrate intake were $6-10 \mathrm{~g} / \mathrm{kg} /$ day or a minimum of $55 \%$ and $20-35 \%$ of fat daily intake. The Recommended Dietary Allowances (RDA) from the Food and Nutrition Board/Institute of Medicine (FNB/IM), considering the values of the estimated average requirement, were applied for the micronutrients. As suggested by the ACSM (Rodriguez et al., 2009), BMR was calculated using the Cunningham equation (1980). EA is defined as the amount of EI minus exercise energy expenditure (EEE) normalised to FFM (Loucks et al., 2011; Rodriguez et al., 2009). EEE was calculated using the 2011 Compendium of Physical Activities (Ainsworth et al., 2011). These calculations accounted for exercise duration, the intensity of the gymnastics training and BM, which were collected using a characterisation questionnaire. LEA was defined as EA below $45 \mathrm{kcal} / \mathrm{kg}$ FFM/day (Hoch et al., 2009). A threshold below $30 \mathrm{kcal} / \mathrm{kg} \mathrm{FFM} /$ day was also investigated, since it is associated with amenorrhea and is considered the lowest energy threshold of EA for women (Rodriguez et al., 2009).

\subsection{Statistical analysis}

The characteristics of the participants are described with proportions for categorical variables and with mean and standard deviation values for continuous variables (age, years of practice and training hours). Spearman's correlation coefficient was used to determine associations between categorical and continuous variables. Since there was no control group, the results were compared with reference data and with results from other published studies. The chi-square test was used to distinguish above-adequate and belowadequate categories of macronutrients contribution in intragroup analysis. To compare a group to a hypothetical value, the test for one sample was used. The significance level was 5\% $(\mathrm{P}<0.05)$. Data was analysed using SPSS, version 20.0.

\section{Results}

The majority of the participants $(n=40 ; 59.7 \%)$ had already menstruated, age of menarche was delayed $(15.3 \pm 1.3$ years $)$ and all revealed menstrual irregularities: primary amenorrhea $(2.5 \%)$, secondary amenorrhea (60.2\%) and oligomenorrhea (37.3\%), according to ASRM (2008). Sixteen (23.9\%) gymnasts were taking oral contraceptives and $29.9 \%$ medication for injury recovery, asthma and allergies. The use of sleep medication and vitamin or mineral supplements was also mentioned. Gymnasts' BM $(48.4 \pm 4.9 \mathrm{~kg})$ and BMI $\left(17.4 \pm 1.1 \mathrm{~kg} / \mathrm{m}^{2}\right)$ were below the normal for age (10th to 50th percentiles) and height $(1.66 \pm 0.05 \mathrm{~m})$ was normal to slightly above normal for age (50th to 75th percentiles). Although BF is highly dependent on sex and age, gymnasts' BF was below the estimated minimal value compatible with health for female athletes (Rodriguez et al., 2009). Age strata, BM, height and BMI were significantly greater in gymnasts with ages between 19 and 26 years. However, there were no significant differences in training volume and other parameters of body composition (Table I). The average carbohydrate and protein intakes were $5.1 \pm$ $2.3 \mathrm{~g} / \mathrm{kg} / \mathrm{day}$ and $1.6 \pm 04 \mathrm{~g} / \mathrm{kg} / \mathrm{day}$, which correspond to $51.4 \pm 7.2 \%$ (below the minimum recommended level of $55 \%$ ) and $16.9 \pm 3.4 \%$ of total EI,

Table I. Training volume, body composition and daily energy and macronutrient intakes of gymnasts $(\mathrm{n}=67)$, according to age strata

\begin{tabular}{|c|c|c|c|}
\hline & $16-18$ years $(n=36)$ & $19-26$ years $(n=31)$ & $\mathrm{P}$ \\
\hline Training (hours/week) & $34.6 \pm 7.2(25-54)$ & $39.0 \pm 7.4(25-54)$ & 0.661 \\
\hline $\mathrm{BM}(\mathrm{kg})$ & $46.7 \pm 5.0(36-55)$ & $50.4 \pm 4.1(42-58)$ & $0.006^{*}$ \\
\hline Height $(\mathrm{m})$ & $1.65 \pm 0.1(1.51-1.73)$ & $1.69 \pm 0.0(1.60-1.83)$ & $0.025^{*}$ \\
\hline BMI $\left(\mathrm{kg} / \mathrm{m}^{2}\right)$ & $17.1 \pm 1.2(14.9-20.2)$ & $17.7 \pm 1.0(14.5-19.2)$ & $0.033^{*}$ \\
\hline WC $(\mathrm{cm})$ & $55.9 \pm 5.4(48-68)$ & $55.5 \pm 4.3(49-67)$ & 0.505 \\
\hline $\mathrm{HC}(\mathrm{cm})$ & $67.4 \pm 8.5(58-88)$ & $68.9 \pm 9.0(57-91)$ & 0.616 \\
\hline $\mathrm{WC} / \mathrm{HC}$ & $0.8 \pm 0.1(0.7-1.0)$ & $0.8 \pm 0.1(0.7-1.0)$ & 0.805 \\
\hline $\mathrm{BF}(\%)$ & $9.0 \pm 2.2(6-16)$ & $9.1 \pm 1.9(6-13)$ & 0.930 \\
\hline FFM (kg) & $28.2 \pm 4.6(20-40)$ & $29.9 \pm 5.5(24-43)$ & 0.180 \\
\hline BMR (kcal/day) & $1119.9 \pm 101.7(937-1384)$ & $1157.6 \pm 122.2(1018-1441)$ & 0.746 \\
\hline TBW (L/day) & $50.2 \pm 4.6(45.6-53.1)$ & $51.9 \pm 1.5(48.7-53.9)$ & 0.895 \\
\hline Energy (kcal/kg FFM/day) & $59.6 \pm 16.7(30-91)$ & $62.1 \pm 14.4(38-89)$ & 0.313 \\
\hline Carbohydrate (g/kg/day) & $5.0 \pm 2.3(1.5-11.5)$ & $5.3 \pm 2.2(2.2-12.1)$ & 0.642 \\
\hline Protein (g/kg/day) & $1.5 \pm 0.4(0.8-2.2)$ & $1.7 \pm 0.4(1.1-2.8)$ & $0.039^{*}$ \\
\hline Fat $(\% /$ day $)$ & $33.1 \pm 5.8(16-43)$ & $32.8 \pm 4.7(20-42)$ & 0.773 \\
\hline
\end{tabular}

*Significant difference at $\mathrm{P}<0.05$. 
Table II. Adequacy of macronutrient intakes of gymnasts according to ADA (Rodriguez et al., 2009)

\begin{tabular}{|c|c|c|c|c|c|c|}
\hline & \multicolumn{3}{|c|}{$16-18$ years $(n=36)$} & \multicolumn{3}{|c|}{$19-26$ years $(n=31)$} \\
\hline & Below n (\%) & Adequate $\mathrm{n}(\%)$ & Above n (\%) & Below n $(\%)$ & Adequate $\mathrm{n}(\%)$ & Above n $(\%)$ \\
\hline Carbohydrate & $16(44.4)$ & $12(33.4)$ & $8(22.2)$ & $15(48.3)^{\mathrm{a}}$ & $14(45.2)$ & $2(6.5)$ \\
\hline Protein & $10(27.8)$ & $15(41.7)$ & $11(30.6)$ & $1(3.2)$ & $12(38.7)$ & $18(58.1)^{\mathrm{b}}$ \\
\hline Fat & $1(2.8)$ & $20(55.6)^{c}$ & $15(41.7)$ & $0(0)$ & $20(64.5)$ & $11(35.5)$ \\
\hline
\end{tabular}

${ }^{a}$ Below-adequate category differs from the adequate and above-adequate categories in intragroup analysis by chi-square test $\left(\chi^{2}=10.13\right.$; $\mathrm{df}=2 ; \mathrm{P}=0.006$ for $19-26$ years).

${ }^{\mathrm{b}}$ Above-adequate category differs from the adequate and below-adequate categories in intragroup analysis by chi-square test $\left(\chi^{2}=14.39\right.$; $\mathrm{df}=2 ; \mathrm{P}=0.001$ for $19-26$ years).

${ }^{\mathrm{c}}$ Adequate category differs from the below-adequate and above-adequate categories in intragroup analysis by chi-square test $\left(\chi^{2}=16.17\right.$; $\mathrm{df}=2 ; \mathrm{P}=0.000$ for $16-18$ years)

respectively, and average fat contribution was $33.0 \pm$ $5.3 \%$. In an inter-group analysis, mean intake of protein in the youngest group and mean of fat in both groups were considered to be adequate, according to ADA guidelines (2009) due to gymnasts' low BM (Table I). Mean intakes of carbohydrate were below the recommended levels in both groups in accordance with ADA recommendations (2009). Gymnasts aged 19-26 years presented slightly but still significantly higher protein intakes than the youngest group $(\mathrm{P}=0.039$, Table $\mathrm{I})$. These findings were confirmed by the chi-square test in an intraanalysis group, as follows: $55.6 \%$ of the youngest group showed significantly adequate intakes of fat and $48.3 \%$ and $58.1 \%$ of the oldest group presented significantly below-adequate intakes of carbohydrate and above-adequate of protein, respectively (Table II). No protein or amino acids supplements were mentioned by gymnasts. Although protein intake in excess of the RDA is common practice among athletes involved in high-intensity anaerobic sports to maintain optimum physical performance, there are no recommendations for additional dietary protein for gymnasts (Bernardot, 2000).

The average EI of gymnasts was $1709.6 \pm 329.7 \mathrm{~kg} /$ day, where $50.7 \%$ had their EI below $1800 \mathrm{kcal} /$ day, which is a recommended minimum value to maintain a positive energy balance and also to prevent disruption of endocrine function (Rodriguez et al., 2009). The average BMR of gymnasts was $1137.4 \pm 112.3$ $\mathrm{kcal} /$ day.

Regarding EA, no significant differences ( $\mathrm{P}>$ 0.05) were observed between groups (Table III).
Furthermore, the mean EEE calculated for both groups was $789.9 \pm 243.7 \mathrm{kcal} /$ day and the EA was $31.5 \pm 11.9 \mathrm{kcal} / \mathrm{kg}$ FFM/day. These findings may compromise gymnasts' energy needs for growth, maturation and athletic performance (Nattiv et al., 2007), since $37.3 \%$ of gymnasts presented LEA below $45 \mathrm{kcal} / \mathrm{kg}$ FFM/day $(33.3 \%$ in the youngest and $41.9 \%$ in the oldest) and $44.8 \%$ of gymnasts demonstrated EA below $30 \mathrm{kcal} / \mathrm{kg}$ FFM/day. We also found that although gymnasts of 19-26 years showed significantly $(\mathrm{P}=0.008)$ higher average EI than the youngest group (1802.9 $\pm 289.4 \mathrm{kcal} /$ day vs. $1629.2 \pm 344.8 \mathrm{kcal} /$ day), they also demonstrated significantly $(\mathrm{P}=0.04)$ higher $\operatorname{EEE}(899.1 \pm 222.4$ $\mathrm{kcal} /$ day vs. $695.9 \pm 223.5 \mathrm{kcal} /$ day), resulting in lower EA $(29.8 \pm 10.8 \mathrm{kcal} / \mathrm{kg}$ FFM/day vs. $32.9 \pm$ $12.8 \mathrm{kcal} / \mathrm{kg}$ FFM/day - Table III). This may suggest that the oldest group might be at a greater risk for developing health and physical performance hazards than the youngest one, such as negative musculoskeletal effects, bone stress injuries and low bonemineral density.

The majority of gymnasts reported low intakes of important vitamins including folate, vitamins $\mathrm{D}, \mathrm{E}$ and $\mathrm{K}$ and minerals, including calcium, iron, boron and magnesium (FNB/IM, 2011, 1999, 2001, 2000 Table IV). No significant differences $(\mathrm{P}>0.05)$ were observed between RDA for iron and phosphorus in gymnasts aged 16-18 years and for magnesium in gymnasts aged 19-26 years (FNB/IM, 2001). On the other hand, intakes of thiamine, riboflavin, niacin, vitamins $\mathrm{A}, \mathrm{B}-6, \mathrm{~B}-12$ and $\mathrm{C}$ were above-adequate, as well as for manganese and zinc $(\mathrm{P}<0.05$;

Table III. EA, EI and EEE of gymnasts $(n=67)$, according to age strata

\begin{tabular}{lccc}
\hline & $16-18$ years $(\mathrm{n}=36)$ & $19-26$ years $(\mathrm{n}=31)$ & $\mathrm{P}$ \\
\hline EA (kcal/kg FFM/day) & $32.9 \pm 12.8(26-59)$ & $29.8 \pm 10.8(24-52)$ & 0.915 \\
EI (kcal/day) & $1629.2 \pm 344.8(979-2177)$ & $1802.9 \pm 289.4(1027-2320)$ & $0.008^{*}$ \\
EEE (kcal/day) & $695.9 \pm 223.5(445-1369)$ & $899.1 \pm 222.4(479-1303)$ & $0.04^{*}$ \\
\hline
\end{tabular}

*Significant difference at $\mathrm{P}<0.05$. 
Table IV. Micronutrient intakes of both groups of gymnasts (16-18 years and 19-26 years) comparing with the RDA from the FNB/IM

\begin{tabular}{|c|c|c|c|c|c|c|c|}
\hline \multirow[b]{2}{*}{ Micronutrients } & \multicolumn{3}{|c|}{$16-18$ years $(n=36)$} & \multicolumn{3}{|c|}{$19-26$ years $(\mathrm{n}=31)$} & \multirow[b]{2}{*}{$\mathrm{P}$} \\
\hline & Mean \pm SD & RDA & $\mathrm{P}$ & Mean \pm SD & RDA & $\mathrm{P}$ & \\
\hline Thiamine (mg/day) & $1.8 \pm 1.2$ & 1.0 & 0.000 & $2.0 \pm 1.1$ & 1.1 & 0.000 & 0.449 \\
\hline Riboflavin (mg/day) & $2.2 \pm 1.5$ & 1.0 & 0.000 & $2.6 \pm 1.3$ & 1.1 & 0.000 & 0.246 \\
\hline Niacin (mg/day) & $23 \pm 17$ & 14 & 0.000 & $27 \pm 16$ & 14 & 0.000 & 0.397 \\
\hline Pantothenic acid (mg/day) & $4 \pm 1$ & 5 & 0.000 & $5 \pm 2$ & 5 & 0.000 & 0.065 \\
\hline Vitamin B-6 (mg/day) & $2.1 \pm 1.7$ & 1.2 & 0.000 & $2.5 \pm 1.5$ & 1.3 & 0.000 & 0.350 \\
\hline Folate $(\mu \mathrm{g} /$ day $)$ & $286 \pm 327$ & 400 & 0.013 & $328 \pm 275$ & 400 & 0.015 & 0.585 \\
\hline Vitamin B-12 ( $\mu \mathrm{g} /$ day $)$ & $3.9 \pm 2.1$ & 2.4 & 0.000 & $4.3 \pm 1.6$ & 2.4 & 0.000 & 0.476 \\
\hline Vitamin A ( $\mu \mathrm{g} /$ day $)$ & $1272 \pm 1252$ & 700 & 0.000 & $1670 \pm 1140$ & 700 & 0.000 & 0.182 \\
\hline Vitamin C (mg/day) & $81 \pm 59$ & 65 & 0.000 & $90 \pm 46$ & 75 & 0.000 & 0.537 \\
\hline Vitamin D ( $\mu \mathrm{g} /$ day $)$ & $3 \pm 3$ & 15 & 0.000 & $3 \pm 2$ & 15 & 0.000 & 0.688 \\
\hline Vitamin E (mg/day) & $6 \pm 2$ & 15 & 0.000 & $6 \pm 3$ & 15 & 0.000 & 0.349 \\
\hline Vitamin $\mathrm{K}(\mu \mathrm{g} /$ day $)$ & $15.2 \pm 8.4$ & 75 & 0.000 & $16.4 \pm 9.0$ & 90 & 0.000 & 0.549 \\
\hline Calcium (mg/day) & $704 \pm 240$ & 1300 & 0.000 & $876 \pm 257$ & 1000 & 0.000 & $0.008^{\mathrm{b}}$ \\
\hline Iron (mg/day) & $13 \pm 10$ & 15 & $0.294^{\mathrm{a}}$ & $15 \pm 9$ & 18 & 0.001 & 0.537 \\
\hline Boron (mg/day) & $5 \pm 3$ & 17 & 0.000 & $6 \pm 4$ & 20 & 0.000 & 0.176 \\
\hline Magnesium (mg/day) & $220 \pm 93$ & 360 & 0.002 & $300 \pm 362$ & 310 & $0.094^{\mathrm{a}}$ & 0.229 \\
\hline Manganese (mg/day) & $2.2 \pm 1.4$ & 1.6 & 0.018 & $3.9 \pm 6.8$ & 1.8 & 0.042 & 0.171 \\
\hline Phosphorus (mg/day) & $1048 \pm 259$ & 1250 & $0.288^{\mathrm{a}}$ & $1338 \pm 681$ & 700 & 0.000 & $0.026^{\mathrm{b}}$ \\
\hline Zinc (mg/day) & $9 \pm 4$ & 9 & 0.001 & $13 \pm 6$ & 8 & 0.000 & $0.003^{\mathrm{b}}$ \\
\hline Fibre (g/day) & $14 \pm 6$ & 26 & 0.000 & $3 \pm 2$ & 25 & 0.000 & $0.027^{\mathrm{b}}$ \\
\hline Water (L/day) & $1.4 \pm 0.5$ & 2.3 & 0.000 & $1.5 \pm 0.4$ & 2.7 & 0.000 & 0.151 \\
\hline
\end{tabular}

${ }^{\mathrm{a}}$ No significant differences were observed between minerals and the RDA ( $\left.\mathrm{P}>0.05\right)$. ${ }^{\mathrm{b}}$ Significant differences were observed in micronutrients intakes between the two groups of gymnasts $(\mathrm{P}<0.05)$. The data do not include vitamin and mineral supplements.

FNB/IM，2001， 2000, 1999). In an inter-group analysis, gymnasts did not show significant group differences $(\mathrm{P}>0.05)$ in micronutrients intake, with exception for calcium $(\mathrm{P}=0.008)$, phosphorus $(\mathrm{P}=$ $0.026)$ and zinc $(P=0.003$ - Table IV), due to higher mean intakes in the oldest group (Table IV). Although both groups demonstrated fibre and water below the recommended RDA (26 g/day for fibre and $2.3 \mathrm{~L} /$ day for water in the youngest group and $25 \mathrm{~g} /$ day for fibre and $2.7 \mathrm{~L} /$ day for water in the oldest group; FNB/IM, 2005a, 2005b), significant group differences $(\mathrm{P}<0.05)$ were found in fibre intake, due to the very low mean intake in the oldest group (3.3 \pm $2.1 \mathrm{~g} /$ day - Table IV).

\section{Discussion}

This is one of the few studies evaluating dietary intakes and body composition of female gymnasts prior to competition, since previous studies were mostly conducted during training sessions. Additionally, our study is one of the few to present adequate mean intakes of protein and fat but low mean intake of carbohydrate in young RG. No published studies evaluating EA in gymnasts were found.

Gymnasts began exercise at early ages (6-7 years) and presented high performance levels (Soric, Misigoj-Durakovic, \& Pedisic, 2008). Since gymnasts were involved in the competitive period of the athletic season, normally characterised by a strict control of energy input in combination with a high energy output, reduced levels of BM and BMI for age were expected. Gymnasts' height was slightly higher than in previous data (Georgopoulos et al., 2012).

Gymnasts presented low BF (considered as a determinant for the quality of athletic performance), which was below the minimum recommended level of $12 \%$ compatible with health for female athletes (Rodriguez et al., 2009). Thus, a delay of 2 years in menarche was observed in agreement with the results reported by Douda et al. (2008). Given that menstruation is disturbed when BF decreases that "critical threshold", these findings are in agreement with the presence of menstrual irregularities (ASRM, 2008). In spite of low EI (1709.6 $\pm 329.7 \mathrm{kcal} /$ day $)$ reported, energy demands were high and gymnasts exhibited LEA $(31.5 \pm 11.9 \mathrm{kcal} / \mathrm{kg}$ FFM/day $)$. Furthermore, the reduced EI affected mainly the younger group of athletes. The oldest group showed a worrying LEA (slightly lower than $30 \mathrm{kcal} / \mathrm{kg} \mathrm{FFM} /$ day) and only $9.7 \%$ of them reported EA higher than $45 \mathrm{kcal} / \mathrm{kg}$ FFM/day. These data might suggest that this combination of strenuous training and prolonged LEA may result in menstrual dysfunction due to altered hypothalamic-pituitary function and may negatively affect the release of gonadotropin, which may lead to abnormal menarche as well as growth (including bone health, immune response and reproductive function) and performance impairment (Klentrou \& Plyley, 2003; Loucks \& Redman, 2004; Manore et al., 
2007). Furthermore, considering the high prevalence of menstrual irregularities among gymnasts and the LEA, we may posit a causal relationship between LEA and the induction of menstrual disorders. Since a high number of gymnasts (62.7\%) suffered from amenorrhoea and $44.8 \%$ of gymnasts demonstrated EA $<30 \mathrm{kcal} / \mathrm{kg} \mathrm{FFM} / \mathrm{day}$, it is possible that they suffered from functional hypothalamic amenorrhoea, which is typically caused by LEA. In functional hypothalamic amenorrhoea, ovarian function is suppressed by an abnormally slow frequency of luteinizing hormone pulses in the blood (Manore et al., 2007). The disruption of luteinizing hormone pulsatility occurs at a threshold of EA not higher than 30 $\mathrm{kcal} / \mathrm{kg} \mathrm{FFM/day} \mathrm{(Loucks} \mathrm{\&} \mathrm{Redman,} \mathrm{2004).} \mathrm{The}$ resolution addresses some strategies to restore reproductive and metabolic hormones and to avoid abnormal menarche and stress fractures, as follows: increase EA by increasing food intake or decrease energy expenditure by reducing training volume. Food intake increase should be assured by increasing carbohydrate or protein intakes rather than reducing fat intakes (Jeukendrup \& Cronin, 2011).

Gymnasts were also very time limited between and within training sessions and preparing to compete, therefore applying for more than one day of dietary intakes was difficult. Nevertheless, in the current study, gymnasts were asked to provide information about typical diet, and the results were in accordance with the overall trend for RG (D'Alessandro et al., 2007; Deutz et al., 2000; Michopoulou et al., 2011; Soric et al., 2008), so we believe in the reliability of the results. Only two studies (Borms \& Caine, 2003; Moffatt, 1984) presented higher EI values than the present study (mean daily EI was $2300 \mathrm{kcal} /$ day). Deutz et al. (2000) have also observed that the higher the level of competitive gymnasts, the lower their daily EI.

Regarding the ADA's recommendations for macronutrient intakes (2009) expressed relative to gymnasts' body size, gymnasts' nutrition did differ from adequate intakes, since gymnasts aged 19-26 years reported significantly above-adequate levels of protein intake $(\mathrm{P}=0.0039)$ than gymnasts aged $16-18$ years More importantly, in young athletes, carbohydrate intake recommendations highly depend on the type, duration and intensity of physical exercise performed. Therefore, international guidelines should be also considered (Rodriguez et al., 2009), since a diet providing $60 \%$ of carbohydrates may not be sufficient to maintain ideal carbohydrates stores if EI is lower than $2000 \mathrm{kcal} / \mathrm{day}$. The diet considered optimal for athletes should provide plenty of carbohydrates (6-10 $\mathrm{g} / \mathrm{kg} /$ day), enough protein to meet the requirements of resistance training and strength (1.2-1.7 g/kg/day) and a reduced contribution of fat $(20-35 \%)$ in order to prevent increase of adipose tissue and to reduce the risk of chronic diseases (Rodriguez et al., 2009). Therefore, some gymnasts may be at risk to maintain ideal carbohydrates stores, since they reported low EI and did not meet the minimum recommended level of $55 \%$ of carbohydrate intakes (Manore et al., 2007). Controversial results have been demonstrated in relation to gymnasts' macronutrient intakes. Some studies (Nova, Montero, Lopez-Varela, \& Marcos, 2001; Soric et al., 2008) demonstrated low intakes of carbohydrate and high intakes of protein and fat, contrary to Michopoulou et al. (2011).

Although not the case with the gymnasts in our study, we consider it important to note from our experience that in gymnastics training sessions of high intensity, energy restriction is common among female athletes in order to reduce BM (Baldari \& Guidetti, 2001; Deutz et al., 2000). In this case, the American Academy of Pediatrics Committee on Sports Medicine and Fitness (2005) stated that it should be done gradually with not more than $1.5 \%$ of the total BM lost per week, since a greater BM loss may result in muscle protein breakdown and can even influence growth and development.

Micronutrient intake was higher among the oldest gymnasts. However, both age groups have significantly inadequate intakes of essential micronutrients that may impact on growth and maturation, skeletal development and reproductive function (Bernardot, 2000), with the exception of iron (Michopoulou et al., 2011) and phosphorus intake, which was within the optimal range in the youngest group and of magnesium in the oldest group. According to our findings, both groups of gymnasts presented menstrual irregularities, and the oldest one even revealed significantly low levels of iron $(\mathrm{P}=0.001)$; therefore, it is possible that gymnasts may be at risk for the presence of anaemia (Bernardot, 2000; Michopoulou et al., 2011). The most significantly compromised micronutrients according to age strata were calcium, phosphorus, zinc and fibre (D'Alessandro et al., 2007; Soric et al., 2008). Michopoulou et al. (2011) also observed deficits in fibre, water and calcium intakes in gymnasts as published elsewhere (D'Alessandro et al., 2007; Soric et al., 2008); in phosphorus (D'Alessandro et al., 2007; Soric et al., 2008); in vitamin A and niacin (Soric et al., 2008) and in iron and zinc (D'Alessandro et al., 2007). In the study of Jonnalagadda, Bernardot, and Nelson (1998) with the American Women's Artistic Team ( $\mathrm{n}=33$ ), calcium, zinc and magnesium intake was lower than the recommended, showing some similarity with the results of this study. In spite of the surprisingly low consumption of water and fibre, it is important that gymnasts should be informed that thirst is reported to be a poor indicator of fluid needs (Jeukendrup \& Cronin, 2011). Gymnasts did not report consumption of beverages containing 
carbohydrates or electrolytes before, during or after training sessions. Therefore, they should be encouraged to drink enough fluid before, during and after physical exercise to be well hydrated and to balance fluid losses during exercise. Gymnasts should be also informed about the well-known importance of adequate fibre intakes to minimise gastrointestinal distress and to regulate appetite. Regarding the negative EA and imbalanced vitamin and mineral intakes observed, it is clear that supplements may be provided and individualised nutritional assessment is required. According to ADA (2009) calcium and vitamin D supplementation is required, as follows: $1500 \mathrm{mg} /$ day of elemental calcium and 400-800 IU of vitamin D/day. Calcium is especially important for growth, maintenance and repair of bone tissue, maintenance of blood calcium levels and normal blood clotting. Vitamin $\mathrm{D}$ is required for adequate calcium absorption, regulation of serum calcium and phosphorus levels and promotion of bone health (FNB/IM, 2011). Education programmes to increase gymnasts', coaches' and parents' knowledge about health, basic nutrition and athletic performance, as well as the risks associated with low BF and LEA should be implemented as a preventive strategy.

The limitations of this study should be taken into account when interpreting these results. First, estimating dietary intakes is difficult (Borms \& Caine, 2003; Deutz et al., 2000), especially prior to a competition. Most gymnasts travelled across different time zones to compete in an environment that may be both geographically distant and different from the home-base, which can have an impact on food intake (Reilly, Waterhouse, Burke, Alonso, \& International Association of Athletics Federations, 2007). On the other hand, energy assessment based on 24-h units implies loss of important data, day-today variations related to EI (Deutz et al., 2000) and depends on an individual's ability to accurately record the type and quantity of food consumed. In addition, given the frequent reports suggesting individual energy restriction among advanced competitive level female gymnasts, self-reported values for food intake will probably not reflect the exact values (Bernardot, 2000; Borms \& Caine, 2003; D'Alessandro et al., 2007; Deutz et al., 2000; Jonnalagadda et al., 1998; Michopoulou et al., 2011; Moffatt, 1984; Soric et al., 2008;). However, the trends are likely correct and might be supported by the older gymnasts' tendency to maintain a lean physique by restricting energy intake (Borms \& Caine, 2003; Michopoulou et al., 2011). Although gymnasts were motivated and willing to reliably report habitual intake, all techniques for estimating energy and nutrient intakes have the problem of underreporting food intake (Poslusna, Ruprich, de Vries, Jakubikova, \& van't Veer, 2009; Wilson et al., 2014).
Goldberg et al. (1991) considered that daily EI should be over a minimum level of energy expenditure that corresponds to the product of $1.1 \times \mathrm{BMR}$. Applying this calculation to the current study, the minimum level of energy expenditure is $1251 \mathrm{kcal}$ suggesting that daily EI underestimation might have been avoided. Second, although the Cunningham equation has been used to determine energy expenditure rate in several sport-based studies, it was only used to estimate BMR in the present study, since numeric guidelines such as this only provide an approximation of the average energy expenditure of an individual athlete. We, however, emphasise that laboratorial facilities were not available to evaluate the athletes of our study; thus, future studies should measure daily energy expenditure rate prior to competitions, either directly by the doubly labelled water methodology or indirectly via a portable gas exchange analyser. Third, despite the known fluctuations in the frequency of consumption of micronutrients (e.g. to confidently report vitamin $\mathrm{C}$ status can take up to 30 days; Bingham, 1987), it should be said that due to gymnasts' time constraints, the frequency of consumption of some micronutrients may be considered another limitation. On the other hand, the doubly labelled water technique, considered as the gold standard for measuring $\mathrm{EE}$ under free-living conditions might be used to estimate accuracy of self-reported EI in future studies (Poslusna et al., 2009). Finally, the reduction of TBW can be linked to an insufficient fluid intake reported or to a greater requirement because of intensive training. In addition, and as suggested by Rodriguez et al. (2009), bioelectrical impedance can provide fairly accurate estimates of TBW and FFM. However, bioelectrical impedance depends on a number of factors that can cause error in the measurement (e.g. hydration status may alter the estimated percentage BF). To overcome this, similar future studies should employ a handheld refractometer which is a reliable device for measuring urine osmolality (Sparks \& Close, 2013).

\section{Conclusion}

In conclusion, gymnasts revealed low BF, LEA and macro- and micronutrients inadequate intakes for physiological and training demands, specially the youngest gymnasts. Specialised intervention is needed in order to support daily physical activities, growth and maturation and to promote optimal body composition through ensuring adequate energy and nutrient availability.

\section{Acknowledgements}

Both authors were responsible for the conception, design, data analysis and data interpretation of the 
study and writing the manuscript; M.-R. G. Silva was also responsible for data collection. All authors approved the final version of the manuscript. The authors declared no conflict of interest. Authors thank the gymnasts for their participation in this study and the coaches for their collaboration. The authors are also grateful to the reviewers for their valuable comments.

\section{References}

Ainsworth, B. E., Haskell, W. L., Herrmann, S. D., Meckes, N., Bassett, D. R. Jr., Tudor-Locke, C., ... Leon, A. S. (2011). Compendium of physical activities: A second update of codes and MET values. Medicine \& Science in Sports \& Exercise, 43, 1575-1581. doi:10.1249/MSS.0b013e31821ece12

American Academy of Pediatrics Committee on Sports Medicine and Fitness. (2005). Promotion of healthy weight-control practices in young athletes. Pediatrics, 116, 1557-1564. doi:10.1542/ peds.2005-2314

American Society for Reproductive Medicine. (2008). Current evaluation of amenorrhea. Fertility and Sterility, 90, S219-S225. doi:10.1016/j.fertnstert.2008.08.038

Baldari, C., \& Guidetti, L. (2001). $\quad \mathrm{VO}_{2} \max$, ventilatory and anaerobic thresholds in rhythmic gymnasts and young female dancers. Journal of Sports Medicine and Physical Fitness, 41, 177182. PMID: 11447359.

Bernardot, D. (2000). Gymnastics. In R. J. Maughan (Ed.), Nutrition in sport (pp. 588-608). London: Blackwell Science.

Bingham, S. (1987). The dietary assessment of individuals, methods, accuracy, new techniques and recommendations. Nutrition Abstracts and Reviews, 57, 705-740.

Borms, J., \& Caine, D. J. (2003). Kinanthropometry. In S. W. A. Editor, C. D. J. Editor, \& B. J. Editor (Eds.), Scientific aspects of women's gymnastics (pp. 110-127). Basel: Karger.

Calavalle, A. R., Sisti, D., Rocchi, M. B., Panebianco, R., Del Sal, M., \& Stocchi, V. (2008). Postural trials: Expertise in rhythmic gymnastics increases control in lateral directions. European Journal of Applied Physiology, 104, 643-649. doi:10.1007/ s00421-008-0815-6

Cunningham, J. J. (1980). A reanalysis of the factors influencing basal metabolic rate in normal adults. The American Journal of Clinical Nutrition, 33, 2372-2374. PMID:7435418.

D’Alessandro, C., Morelli, E., Evangelisti, I., Galetta, F., Franzoni, F., Lazzeri, D., ... Cupisti, A. (2007). Profiling the diet and body composition of subelite adolescent rhythmic gymnasts. Pediatric Exercise Science, 19, 215-227. PMID:17603144.

Deutz, R. C., Benardot, D., Martin, D. E., \& Cody, M. M. (2000). Relationship between energy deficits and body composition in elite female gymnasts and runners. Medicine \& Science in Sports \& Exercise, 32, 659-668. PMID:10731010. doi:10.1097/00005768-200003000-00017

Douda, H. T., Toubekis, A. G., Avloniti, A. A., \& Tokmakidis, S. P. (2008). Physiological and anthropometric determinants of rhythmic gymnastics performance. International Journal of Sports Physiology and Performance, 3(1), 41-54. PMID:19193953.

Food and Nutrition Board/Institute of Medicine. (1999). Dietary reference intakes for thiamin, riboflavin, niacin, vitamin B6, folate, vitamin B12, pantothenic acid, biotin, and choline. Washington, DC: National Academies Press. Retrieved from http://www. nap.edu/catalog.php?record_id $=6015$

Food and Nutrition Board/Institute of Medicine. (2000). Dietary reference intakes for vitamin $\mathrm{C}$, vitamin $\mathrm{E}$, selenium, and carotenoids. Washington, DC: National Academies Press. Retrieved from http://www.nap.edu/catalog.php?record_id=9810
Food and Nutrition Board/Institute of Medicine. (2001). Dietary reference intakes for vitamin $\mathrm{A}$, vitamin $\mathrm{K}$, arsenic, boron, chromium, copper, iodine, iron, manganese, molybdenum, nickel, silicon, vanadium, and zinc. Washington, DC: National Academies Press. Retrieved from http://www.nap.edu/catalog/10026.html

Food and Nutrition Board/Institute of Medicine. (2005a). Dietary reference intakes for energy, carbohydrate, fiber, fat, fatty acids, cholesterol, protein and amino acids. Washington, DC: National Academies Press. Retrieved from http://www.nap.edu/catalog. php?record_id=10490

Food and Nutrition Board/Institute of Medicine. (2005b). Dietary reference intakes for water, potassium, sodium, chloride, and sulfate. Washington, DC: National Academies Press. Retrieved from http://www.nap.edu/catalog/10925.html

Food and Nutrition Board/Institute of Medicine. (2011). Dietary reference intakes for calcium and vitamin D. Washington, DC: National Academies Press. Retrieved from http://www.nap.edu/ catalog.php?record_id $=13050$

Frisancho, A. R. (2008). Anthropometric standards: An interactive nutritional reference of body size and body composition for children and adults. Ann Arbor: The University of Michigan Press. Retrieved from http://babel.hathitrust.org/cgi/pt?id=mdp.39015082696876; view=1up;seq=3

Georgopoulos, N. A., Theodoropoulou, A., Roupas, N. A., Rottstein, L., Tsekouras, A., Mylonas, P., ... Markou, K. B. (2012). Growth velocity and final height in elite female rhythmic and artistic gymnasts. Hormones (Athens), 11(1), 6169. PMID:22450345.

Goldberg, G. R., Black, A. E., Jebb, S. A., Cole, T. J., Murgatroyd, P. R., Coward, W. A., \& Prentice, A. M. (1991). Critical evaluation of energy intake data using fundamental principles of energy physiology: 1. Derivation of cut-off limits to identify under-recording. European Journal of Clinical Nutrition, 45, 569-581. PMID:1810719.

Hoch, A. Z., Pajewski, N. M., Moraski, L., Carrera, G. F., Wilson, C. R., Hoffmann, R., ... Gutterman, D. D. (2009). Prevalence of the female athlete triad in high school athletes and sedentary students. Clinical Journal of Sport Medicine, 19, 421-428. doi:10.1097/JSM.0b013e3181b8c136

Jeukendrup, A., \& Cronin, L. (2011). Environmental factors affecting elite young athletes. Medicine and Sport Science, 56, 47-58. doi:10.1159/000320646

Jonnalagadda, S. S., Bernadot, D., \& Nelson, M. (1998). Energy and nutrient intakes of the United States national women's artistic gymnastics team. International Journal of Sport Nutrition, 8, 331-344. PMID:9841954.

Klentrou, P., \& Plyley, M. (2003). Onset of puberty, menstrual frequency, and body fat in elite rhythmic gymnasts compared with normal controls. British Journal of Sports Medicine, 7, 490494. doi:10.1136/bjsm.37.6.490

Loucks, A. B., Kiens, B., \& Wright, H. H. (2011). Energy availability in athletes. Journal of Sports Sciences; 29, S7-S15. doi:10.1080/02640414.2011.588958

Loucks, A. B., \& Redman, L. M. (2004). The effect of stress on menstrual function. Trends in Endocrinology \& Metabolism, 10, 466-471. doi:10.1016/j.tem.2004.10.005

Magkos, F., \& Yannakoulia, M. (2003). Methodology of dietary assessment in athletes: concepts and pitfalls. Current Opinion in Clinical Nutrition and Metabolism Care, 6, 539-549. PMID: 12913671.

Manore, M. M., Kam, L. C., Loucks, A. B., \& International Association of Athletics Federations. (2007). The female athlete triad: Components, nutrition issues, and health consequences. Journal of Sports Sciences, 25, S61-S71. doi:10.1080/ 02640410701607320

Marfell-Jones, M. (2006). International standards for anthropometric assessment. Potchefstroom: ISAK. 
Michopoulou, E., Avloniti, A., Kambas, A., Leontsini, D., Michalopoulou, M., Tournis, S., \& Fatouros, I. G. (2011). Elite premenarcheal rhythmic gymnasts demonstrate energy and dietary intake deficiencies during periods of intense training. Pediatric Exercise Science, 23, 560-572. PMID:22109784.

Moffatt, R. J. (1984). Dietary status of elite female high school gymnasts: Inadequacy of vitamin and mineral intake. Journal of the American Dietetic Association, 84, 1361-1363. PMID:6491118.

Nattiv, A., Loucks, A. B., Manore, M. M., Sandorn, C. F., Sundgot-Borgen, J., Warren, M. P., \& American College of Sport Medicine. (2007). American college of sport medicine position stand. The female athlete triad. Medicine and Science in Sports and Exercise, 39, 1867-1882. PMID:17909417.

Nova, E., Montero, A., López-Varela, S., \& Marcos, A. (2001). Are elite gymnasts really malnourished? Evaluation of diet, anthropometry and immunocompetence. Nutrition Research, 21, 15-29. doi:10.1016/S0271-5317(00)00297-9

Poslusna, K., Ruprich, J., de Vries, J. H., Jakubikova, M., \& van't Veer, P. (2009). Misreporting of energy and micronutrient intake estimated by food records and 24 hour recalls, control and adjustment methods in practice. British Journal of Nutrition, 101, S73-S85. doi:10.1017/S0007114509990602
Reilly, T., Waterhouse, J., Burke, L. M., Alonso, J. M., \& International Association of Athletics Federations. (2007). Nutrition for travel. Journal of Sports Sciences, 25, S125-S134. doi:10.1080/02640410701607445

Rodriguez, N. R., DiMarco, N. M., Langley, S., American Dietetic Association, Dietitians of Canada, \& American College of Sports Medicine. (2009). Position of the American dietetic association, dietitians of Canada and the American college of sports medicine: Nutrition and athletic performance. Journal of the American Dietetic Association, 109, 509-527. doi:10.1016/j.jada.2009.01.005

Soric, M., Misigoj-Durakovic, M., \& Pedisic, Z. (2008). Dietary intake and body composition of prepubescent female aesthetic athletes. International Journal of Sport Nutrition and Exercise Metabolism, 18, 343-354. PMID:18562778.

Sparks, S. A., \& Close, G. L. (2013). Validity of a portable urine refractometer: The effects of sample freezing. Journal of Sports Sciences, 31, 745-749. doi:10.1080/02640414.2012.747693

Wilson, G., Hawken, M. B., Poole, I., Sparks, A., Bennett, S., Drust, B., ... Close, G. L. (2014). Rapid weight-loss impairs simulated riding performance and strength in jockeys: Implications for making-weight. Journal of Sports Sciences, 32, 383-391. doi: $10.1080 / 02640414.2013 .825732$ 